\title{
Implementation of Work Rotation Model at the YPDR Nursing Academy Jakarta
}

\author{
Erialdy \\ Universitas Islam Syekh-Yusuf, Indonesia \\ Corresponding author email: erialdy@unis.ac.id \\ Sutarman \\ Universitas Islam Syekh-Yusuf, Indonesia \\ Email: sutarman@unis.ac.id \\ Agus Iwan Mulyanto \\ Universitas Islam Syekh-Yusuf, Indonesia \\ Sugeng Lubar Prastowo \\ Universitas Islam Syekh-Yusuf, Indonesia
}

\begin{abstract}
Work rotation is an employment activity related to the process of transferring functions, responsibilities, and employee status, to obtain work satisfaction and increase maximum work performance. Work rotation functions for the development of human resources which are believed to provide many benefits to the organization. This study aims to determine organizational considerations in implementing employee work rotation activities so that a model will be created that will be used as the basis for employee rotation. This study uses descriptive qualitative methods, data analysis was carried out, using four stages, namely data collection, data reduction, data presentation, and drawing conclusions or verification. Testing the validity of the data using source triangulation techniques. The results of the study conclude that the work rotation model at the YPDR Nursing Academy Jakarta refers to tenure, appraisal work performance results, educational qualifications, skills, and experience and has considered aspects of planning, implementation, and evaluation, with the ultimate goal of optimizing performance institution.

Keywords---educational qualifications, implementation, nursing academy, work performance, work rotation.
\end{abstract}

\section{Introduction}

Employee development programs are carried out by institutions, organizations, or companies to increase the ability of employee performance effectively and efficiently, including by doing work rotation. Work rotation is a phenomenon that usually occurs in institutions, organizations, or companies. Work rotation is an important approach to work design as well as human resource development policies that have the potential to increase work satisfaction and improve employee capabilities (Saravani \& Abbasi, 2013). When one activity is no longer challenging, the employee is transferred to another work, usually at the same level, which has the same skill requirements. Besides functioning as human resource development, work rotation is believed to also provide many other benefits for organizations such as easier work scheduling, managing employee leave, and adapting to changes.

There is a positive and significant impact of work rotation on improving employee performance (Rashki et al., 2014). Employee rotation can not only reduce the level of work saturation but can also increase the competence of workers because with work rotation the knowledge and ability of employees can be improved (Kaymaz, 2010). Work rotation is not an impromptu plan, it must be planned with the aim of avoiding unwanted problems in the future, including failure of the rotation which has an impact on the loss of funds that have been spent by the organization (Sobandi, 2018). 
Work rotation is not without defects, because training costs will increase, productivity will decrease due to moving employees to new positions, there are adjustments again due to new employees in a group (Campion et al., 1994). There were many complaints from employees regarding work rotation, including the time span of work rotation, less comprehensive rotation, demands for the diversity of skills, and difficulties in adapting to a new work environment (Ho et al., 2009).

Without proper work rotation planning, the implementation that does not pay attention to the right man on the right job can lead to work rotation as a routine activity that is less meaningful and does not provide added value to an institution, organization, or company. Therefore, it is necessary to have an appropriate work rotation model that can be implemented, so that the implementation of this work rotation can contribute to the optimization of the performance of institutions, organizations, and companies.

Based on the formulation and problems above, research on the implementation of the worker rotation model needs to be done. The results of this study are expected to provide a positive discourse for leaders to optimize employee work rotation (Furnham \& Hughes, 1999; Fægri et al., 2010). Giving encouragement or motivation for employees to further improve their performance is also expected to have very large leverage towards improving employee performance which in turn will increase the productivity of institutions, organizations, and companies.

\section{Theoretical Framework \\ Implementation}

Its core implementation is an activity to distribute policy outputs (to deliver policy outputs) carried out by implementers to target groups as an effort to realize policy objectives (Purwanto, 2012). Implementation will begin with a series of activities managing regulations, forming organizations, mobilizing people, resources, technology, establishing procedures, and so on with the aim that the stated policy objectives can be realized.

\section{Work rotation}

Human resources in the company need to be managed properly and professionally to create a balance between the needs of employees and the demands and capabilities of the company organization (Mangkunegara, 2000). One of the successes of the performance of a company is determined by the increase in employee performance, and it can be created by managing human resources professionally. Employee performance is influenced by several factors, one of the factors is work rotation. Work rotation is the periodic change of an employee from one task to another (Robbins \& Judge, 2008). Work rotation can prevent boredom and can also reduce employee labor turnover (absence of workers) (Nurlatifah, 2009). Work rotation can indirectly provide benefits to the organization because employees who have many skills can adapt to change.

Work rotation applied to employees should be varied according to the characteristics, competence of the institution and individual employees, as well as the health condition of the institution. However, there is a general principle that should be applied by institutions that rotation must be based on the dimensions of humanity, organization, employee development or repositioning, justice, transparency, and accountability and be sustainable. Employee rotation should avoid pragmatic characteristics such as employee refreshments, and focus more on human resource development, which focuses on the development and enhancement of employee capabilities, especially in areas deemed important for optimizing institutional performance. The formulation of employee rotation should be done with careful preparation, taking into account various aspects such as conformity with the interests and talents of the employees involved in the work rotation. Socialization can be carried out to all employees who will be rotated. With work rotation, employees can start with new tasks and functions and a new worksite (Santoso \& Riyardi, 2012). This is where employees begin to learn, both in their new duties and functions at work, as well as being ready to face various problems and difficulties in their work, which are different from their previous assignments. The employee work rotation model must comprehensively show the plan, implementation, and evaluation of the implementation of work rotation (Muhardi et al., 2017).

\section{Nursing Academy}

The Nursing Academy is an educational institution that organizes the Triple Diploma in Nursing Education Program (Nursing Academy YPDR \& Jakarta, 2015), aims to educate and prepare prospective mid-level nursing experts who are professional in their duties and master the science and technology of Nursing which is the basis of their profession. The director is the leader and the main person responsible for implementing academic activities in the 
Nursing Academy. The Director is assisted by an Assistant Director, namely (a) Assistant Director for Academic Affairs, (b) Assistant Director for General Administration, (c) Assistant Director for Student Affairs. The executing element in charge of assisting the leadership consists of education personnel and non-educational personnel.

\section{Method}

This study uses descriptive qualitative methods. In conducting a study of the work rotation model in optimizing performance at the YPDR Nursing Academy Jakarta, the method used is focused on explaining employee work rotation at the YPDR Nursing Academy Jakarta. The information needed is obtained from the experience of the YPDR Nursing Academy Jakarta which has implemented work rotations for its employees, and also from tracing reference studies that are considered relevant to enrich the discussion in this paper (Harper et al., 2015; Carlson, 2016).

Data collection using in-depth interview techniques, documentation study. Interviews were conducted with: (1) Education Coordinator, representing the YPDR Jakarta Foundation; (2) Director of the YPDR Nursing Academy Jakarta, the person responsible for implementing Institutional Management policies; (3) Assistant Director for Administration and Personnel, the second person who is responsible for the implementation of human resource management. For the documentation study, data was collected from files and documentation owned by the YPDR Nursing Academy Jakarta. Data analysis was carried out, using four stages, namely data collection, data reduction, data presentation, and drawing conclusions or verification. Testing the validity of the data using source triangulation techniques. The research was conducted in 2018.

\section{Results and Discussion}

The YPDR Academy of Nursing Jakarta is an educational institution that provides vocational education in Nursing Diploma three (D3) study programs, based in South Jakarta. With its vision of becoming a YPDR Nursing Academy that excels in the field of Emergency Nursing in developing nursing vocational personnel who are noble and able to compete globally (Nursing Academy YPDR Jakarta, 2018). The YPDR Nursing Academy Jakarta only organizes one study program, therefore there are not many open recruitments, so what is done is employee work rotation to fill vacancies. Every employee has the potential that deserves to be developed, for employees who have good work skills, it will accelerate the achievement of institutional goals, on the other hand, less skilled employees can slow down institutional goals, so there is a need for rotation for equal distribution and improving employee skills so that employees have the opportunity develop yourself more. Employee rotation is based on the principle of The Right Man on The Right Job, which means that employee rotation is carried out to place employees in the right position, as an action to increase work morale and to reduce labor turnover. Rational media competition in the form of work performance appraisal, as a step and for promotion efforts for employees.

The basis for carrying out work rotation refers to the internal rules of the YPDR Nursing Academy Jakarta, namely:

1) Term of office, namely by issuing a decree from the Chairperson of the YPDR Jakarta Foundation, where the term of each office is limited to three years and if necessary can be extended by issuing a new decree.

2) The results of the performance appraisal (appraisal work performance), taking into account the increase in work productivity, increased work motivation, decreased number of work errors, improved attendance, and work discipline, and decreased number of work accidents.

3) Qualifications for education. The higher the education level of employees, the broader their knowledge and abilities will be. Formal and non-formal education is a key element that can change employee behavior in doing something and make it easier for employees to follow developments or changes in their duties.

4) Skills. The ability of employees to carry out work in the form of physical and non-physical skills, skills are the capacities that employees have to do various tasks in one work.

5) Experience. The experience becomes a factor for consideration of work rotation. Employees who have more experience and have a suitable position with the position to be filled will be prioritized for appointment in certain positions. 
Work rotation is an integral part of the organizational system at the YPDR Nursing Academy Jakarta, and its implementation is based on strategic planning, measurable, prospective criteria, and indicators on human resource development. Before the work rotation process is carried out, a mapping of the potential, performance, and behavior of employees in each unit involved in the rotation program is carried out. The implementation of work rotation and the requirements that follow is the policy of the Director of the YPDR Nursing Academy Jakarta because the Director is the one who knows the most about the development of employees and the conditions of the institution, the Assistant Director II in charge of employment issues only functions as a policy implementer. The Director proposes a rotation of employees to the YPDR Jakarta Foundation, which if the foundation is approved, a Decree will be issued and submit the decision letter to the Director for immediate implementation. The YPDR Academy of Nursing Jakarta Work rotation model, as seen in Figure 1, below:

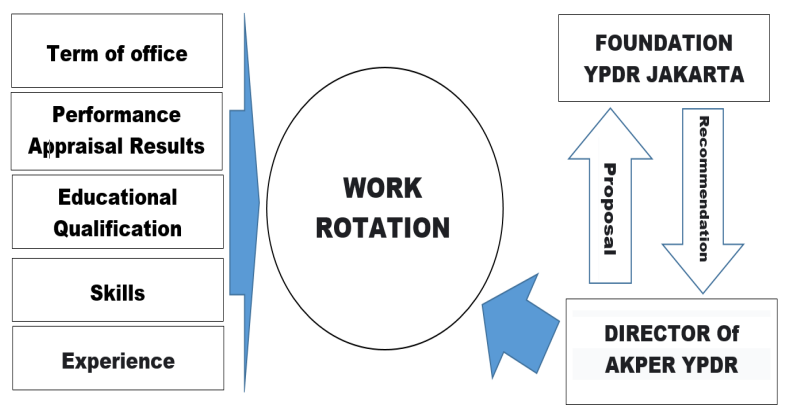

Figure 1. Work rotation model

The leader, in this case, the Director of the YPDR Nursing Academy Jakarta, will always focus on his vision and mission for the good of the institution as a whole. The director with all his powers has a big influence on the formation of a positive work environment, which provides great motivation for employees to be able to provide the best for the institution. Research Rahman \& Solikhah (2016), shows that work rotation has a positive and significant effect on employee performance, meaning that when working rotation increases, employee performance will also increase. The director can improve work dynamics and create a conducive atmosphere in the work environment. Besides, the divisions involved in the work rotation program also have a significant influence on the success of the employee rotation program itself.

In implementing employee rotation, an evaluation of activities is required which should be carried out by the Director regularly. Evaluation of activities in employee rotation is very important to do to measure the development of the ability of employees involved in the work rotation program itself. If the development of an employee's ability after being involved in a work rotation does not match the expectations of the organization, it is better if the employee placement is reviewed. An optimal work rotation program will have a big impact on employees by reducing the level of boredom and work stress, as well as increasing the range of abilities of these employees.

\section{Conclusion}

The work rotation model at the YPDR Nursing Academy Jakarta refers to tenure, appraisal of work performance, educational qualifications, skills, and experience (Pant \& Yadav, 2016). Shows that work rotation has taken into account aspects of planning, implementation, and evaluation, with the ultimate goal of optimizing institutional performance. The implementation of work rotation also takes into account the suitability of the interests and talents of employees, a variety of work skills, which will affect the decrease in employee work saturation so that it will increase cooperation and optimize performance (Battistin et al., 2014; Hango, 2007). Of course, to determine the effectiveness of the implementation of work rotation at the YPDR Nursing Academy Jakarta, periodic evaluations are needed, so that the results can be used as a basis for corrective action.

\section{Acknowledgments}

The authors would like to thank the YPDR Jakarta Education Coordinator, the Director of the YPDR Jakarta Academy of Nursing, and the Assistant Director for Administration and Personnel who supported this research. 


\section{References}

Akademi Keperawatan YPDR Jakarta. (2018). Document Keeper.

Akademi Keperawatan YPDR, \& Jakarta. (2015). Statuta.

Battistin, E., De Nadai, M., \& Sianesi, B. (2014). Misreported schooling, multiple measures and returns to educational qualifications. Journal of $\quad$ Econometrics, 181(2), 136-150. https://doi.org/10.1016/j.jeconom.2014.03.002

Campion, M. A., Cheraskin, L., \& Stevens, M. J. (1994). Career-related antecedents and outcomes of job rotation. Academy of management journal, 37(6), 1518-1542.

Carlson, J. (2016). Baccalaureate nursing faculty competencies and teaching strategies to enhance the care of the veteran population: Perspectives of Veteran Affairs Nursing Academy (VANA) faculty. Journal of Professional Nursing, 32(4), 314-323. https://doi.org/10.1016/j.profnurs.2016.01.006

Fægri, T. E., Dybå, T., \& Dingsøyr, T. (2010). Introducing knowledge redundancy practice in software development: Experiences with job rotation in support work. Information and Software Technology, 52(10), 1118-1132. https://doi.org/10.1016/j.infsof.2010.06.002

Furnham, A., \& Hughes, K. (1999). Individual difference correlates of nightwork and shift-work rotation. Personality and Individual Differences, 26(5), 941-959. https://doi.org/10.1016/S0191-8869(98)00199-8

Hango, D. (2007). Parental investment in childhood and educational qualifications: Can greater parental involvement mediate the effects of socioeconomic disadvantage?. Social science research,36(4), 1371-1390. https://doi.org/10.1016/j.ssresearch.2007.01.005

Harper, D. C., Selleck, C. S., Eagerton, G., \& Froelich, K. (2015). Partnership to improve quality care for veterans: the VA Nursing Academy. Journal of Professional Nursing, 31(1), 57-63. https://doi.org/10.1016/j.profnurs.2014.06.004

Ho, W. H., Chang, C. S., Shih, Y. L., \& Liang, R. D. (2009). Effects of job rotation and role stress among nurses on job satisfaction and organizational commitment. BMC health services research, 9(1), 8.

Kaymaz, K. (2010). The effects of job rotation practices on motivation: A research on managers in the automotive organizations. Business and economics research journal, 1(3), 69-85.

Mangkunegara, A. P. (2000). Manajemen Sumber Daya Manusia Perusahaan, Cetakan Kedua, PT. Remaja Rosdakarya Offset, Bandung.

Muhardi, M., Irfani, A., \& Noviana, N. (2017). MODEL ROTASI KERJA DALAM OPTIMALISASI KINERJA ORGANISASI. Prosiding SNaPP: Sosial, Ekonomi dan Humaniora, 7(3), 783-788.

Nurlatifah. (2009). Pengaruh Rotasi Kerja Terhadap Kinerja Pustakawan di Perpustakaan Universitas Gadjah Mada. Universitas Islam Negeri Sunan Kalijaga Yogyakarta.

Pant, I., \& Yadav, R. K. (2016). Impact of emotional intelligence on the job performance of employee. International research journal of management, IT and social sciences, 3(1), 7-14.

Purwanto, E. A. (2012). Implementasi Kebijakan Publik Konsep dan Aplikasinya di Indonesia (No. 1). 2012.

Rahman, T., \& Solikhah, S. (2016). Analisis Pengaruh Rotasi Kerja, Motivasi Kerja dan Kepuasan Kerja terhadap Kinerja Karyawan di Lembaga Keuangan Mikro Syariah. Muqtasid: Jurnal Ekonomi dan Perbankan Syariah, 7(2), 23-49.

Rashki, Z., Hasanqasemi, A., \& Mazidi, A. (2014). The study of job rotation and staff performance in customs organization of Golestan and Mazandaran Provinces. Kuwait Chapter of the Arabian Journal of Business and Management Review, 3(7), 186.

Robbins, S. P., \& Judge, T. A. (2008). Perilaku organisasi edisi ke-12. Jakarta: Salemba Empat, 11.

Santoso, B., \& Riyardi, A. (2012). Rotasi, mutasi dan promosi karyawan di kantor pelayanan pajak Pratama Klaten.

Saravani, S. R., \& Abbasi, B. (2013). Investigating the influence of job rotation on performance by considering skill variation and job satisfaction of bank employees. Tehnički vjesnik, 20(3), 473-478.

Sobandi, T. A. (2018). Analisis Kebijakan Rotasi Kerja Karyawan Pada Perusahaan Ritel Alfamart. Prosiding FRIMA (Festival Riset Ilmiah Manajemen dan Akuntansi), (1), 123-129. 